\section{The Influence of Climate on Fruit Development and Quality of Four Low-chill Peach Cultivars}

\author{
Todd W. Wert, Jeffrey G. Williamson ${ }^{1}$, Jose X. Chaparro, \\ and E. Paul Miller \\ Department of Horticultural Sciences, University of Florida, 2113 \\ Fifield Hall, Hull Road, Gainesville, FL 32611-0690
}

\author{
Robert E. Rouse \\ Southwest Florida Research and Extension Center, University of Florida, \\ Immokalee, FL 34142
}

Additional index words. Prunus persica, subtropical, temperature, blush, SSC, FDP, TA, Brix, nectarine, fruit size, cultivars, hue, chroma

\begin{abstract}
The effect of climate was observed on fruit quality of four low-chill peach cultivars (Flordaprince, Flordaglo, UFGold, and TropicBeauty). The cultivars were evaluated in three locations (north-central, central, and southwest Florida). Soluble solids content (SSC), titratable acidity (TA), SSC:TA ratio, fruit weight, blush, and fruit development period (FDP) were determined. Longer FDPs were observed at the northcentral location than at the southwest location. Fruit development and the expression of quality attributes were affected by location during fruit growth with higher color and SSC and shorter FDP occurring under warmer conditions. Within locations, 'UFGold' had the shortest FDP except at the southwest location where its chilling requirement may not have been met. At the central and southwest locations, 'UFGold' also tended to have lower TA values and higher SSC; TA ratios than the other cultivars.
\end{abstract}

The production of temperate zone fruit crops in subtropical environments has increased significantly in the last 30 years. Low-chill cultivars of apple, blueberries, plum, and peach have been developed by several breeding programs and are in commercial production (Byrne and Bacon, 1999). This effort has required a significant investment of time and labor because superior commercial quality germplasm was not adapted to low-chill environments and required hybridization with low-quality adapted germplasm for cultivar development (Sherman and Lyrene, 2003). The cultivation of peach in a subtropical environment has revealed that breeding for adaptation did not only require selection for the appropriate chilling requirements, but selection for other traits such as low blind wood (Richards et al., 1994; Wert et al., 2007a), fruit shape (Topp and Sherman, 1989b; Wert et al., 2007b), and fruit set (Lyrene, 2005).

Prevailing climatic conditions can also affect several fruit quality characteristics of peach. Rouse and Sherman (1989a) reported higher blush of several low-chill peach cultivars in the Lower Rio Grande Valley of Texas than in Gainesville, FL. They attributed increased blush coverage to the warmer prevailing temperatures in Texas. However, Topp and Sherman (1989b) reported no correlation between temperature and red

Received for publication 16 July 2008. Accepted for publication 25 Aug. 2008.

${ }^{1}$ To whom reprint requests should be addressed; e-mailjgrw@ufl.edu. blush in 13 different production regions of Australia. Other characteristics such as stylar tip protrusion (Salvador et al., 1998; Topp and Sherman, 1989b) and fruit development period (FDP) (Andersen and Sherman, 1994; Rouse and Sherman, 1989a; Topp and Sherman, 1989b; Weinberger, 1948) can be affected by temperature during fruit development. Overall, higher temperatures during early fruit development reduced FDP. The objective of this experiment was to determine the variation in fruit quality characteristics of four low-chill peach cultivars grown at three locations in Florida.

\section{Materials and Methods}

Three sites were chosen that represented different climates and chilling regimes from north-central to south Florida. The northcentral site was located in Archer, FL (Lake fine sand, long. $29^{\circ} 31^{\prime} \mathrm{N}$, lat. $82^{\circ} 31^{\prime} \mathrm{W}$ ); the second, or central location was in Winter Garden, FL (Calander fine sand, long. 28 $34^{\prime}$ $\mathrm{N}$, lat. $81^{\circ} 34^{\prime} \mathrm{W}$ ); and the third, or southwest location was in Immokalee, FL (Immokalee fine sand, long. $26^{\circ} 25^{\prime} \mathrm{N}$, lat. $81^{\circ} 24^{\prime} \mathrm{W}$ ). Four low-chill peach cultivars (Flordaglo, Flordaprince, TropicBeauty, and UFGold) were planted at all three sites. All four cultivars are early season, low-chill peaches with commercial potential in Florida and are described in greater detail by Okie (1998). 'Flordaprince' is widely grown in the subtropics throughout the world, and both 'Flordaprince' and 'TropicBeauty' have yellow, melting flesh. 'Flordaglo' is a white, melting flesh peach and 'UFGold' has yellow, non- melting flesh. All cultivars were grafted onto a greenleaf rootknot nematode-resistant peach rootstock. Trees were planted in February 2002 at all locations using a north-south row orientation at a distance of $4.57 \mathrm{~m}$ between trees ( 346 trees/ha) in a randomized complete block design with five replications and single tree plots.

Overhead irrigation was used to prevent drought stress and provide frost protection at the north-central site. At the central and southwest locations, trees were irrigated with undertree microsprinklers. Neither the central nor southwest locations received any frost protection.

During 2004, a substantial leak occurred in the irrigation line at the central location and the trees did not receive any irrigation during a 2-week period from mid- to late March.

All trees were winter-pruned to an open vase form and headed back to a height of $\approx 2.5 \mathrm{~m}$. The trees were also summer-pruned as needed. The postemergence herbicide, glyphosate, was used to maintain a weed-free strip under the canopy of the trees and between trees. Locally recommended cultural practices were used for pest and disease management. Fertilizer at the north-central location was applied by hand in three applications: early February, early June, and late September. Fertilizer applications from an adjacent commercial blueberry (Vaccinium corymbosum) field occurred eight times from a mechanical fertilizer spreader on the east side of the trees. These were early February, early March, late March, late May, early July, late July, late August, and early September. When fertilizer was hand-broadcast, it was placed primarily under the west half of the tree to compensate for the unequal distribution of fertilizer from the blueberry planting.

Fertilizer application times at the central location were the same as for the northcentral location. However, reclaimed water was used for irrigation at the central location. Total amount of nitrogen $(\mathrm{N})$ applied through reclaimed irrigation water was obtained by calculating an average $\mathrm{N}$ concentration of reclaimed water $(0.007 \mathrm{~g} \mathrm{~N} / \mathrm{L})$ between July 2005 and Jan. 2006. Emitter output, line pressure, and the irrigation schedule were used to determine total $\mathrm{N}$ applied, which was calculated to be $33.9 \mathrm{~kg} \cdot \mathrm{ha}^{-1} / \mathrm{season}$. Estimates of other essential elements provided by reclaimed irrigation were: $5 \mathrm{~kg} \mathrm{P} / \mathrm{ha} /$ season; $60.5 \mathrm{~kg} \mathrm{~K} / \mathrm{ha} /$ season; $209 \mathrm{~kg} \mathrm{Ca} / \mathrm{ha} /$ season; and $38.0 \mathrm{~kg} \mathrm{Mg} / \mathrm{ha} /$ season. At the southwest location, $16 \mathrm{~N}-4.4 \mathrm{P}-13.3 \mathrm{~K}$ controlled-release fertilizer was applied in March followed by an application of ammonium sulfate during each year. Annual N fertilizer rates were 168 $\mathrm{kg} \cdot \mathrm{ha}^{-1}$ at the north-central location, 103 $\mathrm{kg} \cdot \mathrm{ha}^{-1}$ at the central location, and again 112 $\mathrm{kg} \cdot \mathrm{ha}^{-1}$ at the southwest location.

Visual estimation of bloom was made twice each week (when applicable) using a $10 \%$ to $100 \%$ scale. FDP was determined to be from $50 \%$ to $60 \%$ bloom to first commercial harvest.

Each tree was harvested individually and fruit were classified as either marketable or nonmarketable. Nonmarketable fruit were 
less than $4.5 \mathrm{~cm}$, showed signs of wind scaring, catfacing, bacterial spot, insect predation, split pits, deep suture, or rot. Fruit were harvested at firm ripe when ground color changed from yellow-green to yellow. Harvest occurred at least twice each week at all locations. Ten representative fruit from each tree for each harvest date were selected at random and placed in peach trays that were obtained from a local grocery store. The trays were placed in plastic containers (Rubbermaid ${ }^{\circledR}$, Atlanta, GA) for transport to the laboratory.

Fruit samples were placed in a walk-in cooler $\left(3\right.$ to $\left.5^{\circ} \mathrm{C}\right)$, where they were cooled to remove field heat. Before fruit quality measurements were taken, fruit were removed from the cooler and allowed to warm to room temperature. Each fruit was weighed and rated visually under fluorescent light for the amount of red blush.

In 2005, at first commercial harvest and at midharvest (greatest number of fruit removed per tree), a Konica Minolta CR-400/410 Chroma meter (Konica Minolta, Osaka, Japan) was used to test the chromicity values on the most and least blushed surface areas of five fruit from each 10-fruit subsample. The chroma meter was calibrated using a standard calibration plate before each use. For postharvest measurements in 2005, the same five fruits that were used for chromicity measurements were used for soluble solids concentration (SSC), titratable acidity (TA), and flesh firmness measurements. During 2004, five fruits were selected at random from the 10 -fruit sample for fruit size, weight, and blush at early and midharvest. Fruit were peeled and flesh samples were collected from the cheek area of each fruit. A composite flesh sample was obtained for each five-fruit subsample. Flesh samples were quick-frozen in a $-80^{\circ} \mathrm{C}$ freezer and stored at $-30^{\circ} \mathrm{C}$. Flesh subsamples were removed from the freezer, allowed to thaw at room temperature, and homogenized in a blender. The slurry was centrifuged for $20 \mathrm{~min}$ at $14,000 \mathrm{rpm}$ at $5{ }^{\circ} \mathrm{C}$. The samples were then filtered through two layers of cheesecloth into a $50-\mathrm{mL}$ beaker. Six grams of supernatant diluted with $50 \mathrm{~mL}$ of deionized water was used to measure TA. Samples were titrated to an end point of 8.2 using an automatic titrimeter (Fisher Titrimeter II, No. 9-313-10; Fisher Scientific, Pittsburgh, PA) and expressed as milliliters $0.1 \mathrm{~N}$ $\mathrm{NaOH}$. A digital refractometer (Mark Abbe II Refractometer, Model 10480; Reichert-Jung, Depew, NY) was used to measure the SSC of the remaining undiluted supernatant and was expressed as ${ }^{\circ}$ Brix.

SAS 9.1 (SAS Institute Inc., Cary, NC) was used for statistical analysis. Means were determined using PROC GLM and means separations among and within the locations were by Tukey's honestly significant difference $(P \leq 0.05)$.

\section{Results and Discussion}

As a result of higher rates of $\mathrm{N}$ applied at the north-central location, direct comparisons were not made between this location and the central or southwest locations. Because numerous interactions among cultivar, location, and year were observed, comparisons were made among the cultivars at each location and between the central and southwest locations for each year.

FDPs varied significantly within and among the different locations and cultivars and between years for the central Florida location. However, consistent patterns for FDP among cultivars were observed for the north-central and central locations during 2004 and 2005. Generally, 'TropicBeauty' had the longest FDP followed by 'Flordaglo', Flordaprince', and 'UFGold' (Tables 1-4). This follows published information for FDP of these cultivars (Rouse and Sherman, 1989b; Sherman and Lyrene, 1989, 1997; Sherman et al., 1982). Although 'UFGold' had the shortest FDP at the north-central and central locations each year, in southwest Florida, its FDP was similar to 'TropicBeauty'. The longer FDP calculated for 'UFGold' in southwest Florida may have resulted from a potential error in the estimation of FDP. 'UFGold' did not receive adequate chilling in southwest Florida, thereby extending its bloom period and making it difficult to determine the $50 \%$ to $60 \%$ bloom date.

Although the relative sequence of fruit ripening was similar at the different locations, the lengths of the FDPs differed between locations and years. In general, there was a 10-d reduction for FDP in central

Table 1. Fruit development period, fruit weight, and fruit quality measurements for four low-chill peach cultivars during 2004 for central and southwest Florida.

\begin{tabular}{|c|c|c|c|c|c|c|}
\hline & FDP $^{z}$ (days) & $\begin{array}{c}\mathrm{TA}^{\mathrm{y}} \\
(\mathrm{mL} \mathrm{NaOH})\end{array}$ & $\begin{array}{c}\mathrm{SSC}^{\mathrm{x}} \\
\left({ }^{\circ} \text { Brix }\right)\end{array}$ & $\begin{array}{c}\text { Ratio } \\
\text { (SSC/TA) }\end{array}$ & Blush (\%) & Wt (g) \\
\hline \multicolumn{7}{|l|}{ Central } \\
\hline \multicolumn{7}{|l|}{ Cultivar } \\
\hline Flordaprince & $83 \mathrm{bA}^{\mathrm{w}}$ & $0.95 \mathrm{aA}$ & $12.4 \mathrm{aA}$ & $13.1 \mathrm{abA}$ & $66.7 \mathrm{aB}$ & $87.7 \mathrm{cB}$ \\
\hline Flordaglo & $84 \mathrm{bA}$ & $0.97 \mathrm{aA}$ & $10.6 \mathrm{bA}$ & $11.0 \mathrm{cA}$ & $69.9 \mathrm{aB}$ & $111.7 \mathrm{bA}$ \\
\hline UFGold & $72 \mathrm{cB}$ & $0.90 \mathrm{aA}$ & $11.7 \mathrm{aA}$ & $13.4 \mathrm{aB}$ & $58.9 \mathrm{bB}$ & $73.5 \mathrm{~dB}$ \\
\hline TropicBeauty & $93 \mathrm{aA}$ & $1.01 \mathrm{aA}$ & $11.5 \mathrm{abA}$ & $11.5 \mathrm{bcA}$ & $57.0 \mathrm{bB}$ & $138.2 \mathrm{aA}$ \\
\hline \multicolumn{7}{|l|}{ Southwest } \\
\hline \multicolumn{7}{|l|}{ Cultivar } \\
\hline Flordaprince & $81 \mathrm{bA}$ & $0.94 \mathrm{aA}$ & $11.1 \mathrm{aB}$ & $12.0 \mathrm{bA}$ & $95.3 \mathrm{abA}$ & $93.9 \mathrm{bA}$ \\
\hline Flordaglo & $79 \mathrm{bB}$ & $1.01 \mathrm{aA}$ & $11.3 \mathrm{aA}$ & $11.1 \mathrm{bA}$ & $91.5 \mathrm{bcA}$ & $94.4 \mathrm{bB}$ \\
\hline UFGold & $87 \mathrm{abA}$ & $0.71 \mathrm{bB}$ & $11.2 \mathrm{aA}$ & $16.0 \mathrm{aA}$ & $90.5 \mathrm{cA}$ & $91.1 \mathrm{bA}$ \\
\hline TropicBeauty & $90 \mathrm{aA}$ & $0.90 \mathrm{aA}$ & $10.8 \mathrm{aA}$ & $12.6 \mathrm{bA}$ & $98.2 \mathrm{aA}$ & $113.2 \mathrm{aB}$ \\
\hline
\end{tabular}

${ }^{\mathrm{z}}$ Fruit development period.

yTitratable acidity, mL $0.1 \mathrm{~N} \mathrm{NaOH}$.

xoluble solids content.

${ }^{w}$ Uppercase letters represent significant differences between locations for a specific cultivar. Lowercase letters represent significant differences among cultivars at a given location according to Tukey's test $(P \leq 0.05)$.

Table 2. Fruit development period, fruit weight, and fruit quality measurements for four low-chill peach cultivars during 2004 for north-central Florida.

\begin{tabular}{lcccccc}
\hline Cultivar & $\begin{array}{c}\mathrm{FDP}^{\mathrm{z}} \\
(\text { days })\end{array}$ & $\begin{array}{c}\mathrm{TA}^{\mathrm{y}} \\
(\mathrm{mL} \mathrm{NaOH})\end{array}$ & $\begin{array}{c}\mathrm{SSC}^{\mathrm{x}} \\
\left({ }^{\circ} \mathrm{Brix}\right)\end{array}$ & $\begin{array}{c}\text { Ratio } \\
(\mathrm{SSC} / \mathrm{TA})\end{array}$ & Blush $(\%)$ & Wt $(\mathrm{g})$ \\
\hline Flordaprince & $90 \mathrm{a}^{\mathrm{w}}$ & $0.90 \mathrm{bc}$ & $10.3 \mathrm{ab}$ & $11.5 \mathrm{~b}$ & $57.2 \mathrm{a}$ & $153.2 \mathrm{~b}$ \\
Flordaglo & $98 \mathrm{a}$ & $1.12 \mathrm{ab}$ & $09.8 \mathrm{ab}$ & $9.1 \mathrm{c}$ & $60.0 \mathrm{a}$ & $157.2 \mathrm{ba}$ \\
UFGold & $81 \mathrm{~b}$ & $0.68 \mathrm{c}$ & $09.2 \mathrm{~b}$ & $13.7 \mathrm{a}$ & $43.8 \mathrm{~b}$ & $132.8 \mathrm{c}$ \\
TropicBeauty & $99 \mathrm{a}$ & $1.14 \mathrm{a}$ & $11.2 \mathrm{a}$ & $9.9 \mathrm{bc}$ & $41.1 \mathrm{~b}$ & $164.0 \mathrm{a}$ \\
\hline
\end{tabular}

${ }^{\mathrm{z}}$ Fruit development period.

y Titratable acidity, mL $0.1 \mathrm{~N} \mathrm{NaOH}$.

xSoluble solids content.

wLowercase letters represent significant differences among cultivars according to Tukey's test $(P \leq 0.05)$. 
in FDP during that year. Using the estimates reported by Topp and Sherman (1989a), we would expect a reduction in FDP of 3 to 8 d for 2005 versus 2004, which is similar to the observed 10-d reduction.

Fruit size varied considerably among cultivars at the different locations. Mean fruit weights were greater for 'TropicBeauty' than for 'UFGold' at all locations and both years. 'TropicBeauty' and 'UFGold' are reported to produce peaches averaging $100 \mathrm{~g}$ and $110 \mathrm{~g}$, respectively (Rouse and Sherman, 1989b; Sherman and Lyrene, 1997). In our study, mean fruit weights for 'TropicBeauty' were over $100 \mathrm{~g}$ at all locations and both years. However, 'UFGold' consistently produced fruit with mean weights less than that specified in the release description, especially in central and southwest Florida (Tables 1 and 3).

Competition among fruits for available assimilates may be one possible explanation for the discrepancies in fruit size. Generally, fruit set and cropping were higher for 'UFGold' than for 'TropicBeauty'. In a related study, Wert et al. (2007a) found a greater incidence of blind nodes on 'TropicBeauty' than on 'UFGold'. Blind node development can reduce fruit set and have an effect on fruit size similar to flower or fruit thinning. Moreover, mean fruit size at the north-central location was greater than expected. This may have been the result of additional fertilizer applied to that site $(168 \mathrm{~kg} \mathrm{~N} /$ ha for northcentral Florida versus $103 \mathrm{~kg} \mathrm{~N} / \mathrm{ha}$ and $112 \mathrm{~kg}$ $\mathrm{N} / \mathrm{ha}$ for central and southwest Florida, respectively). Saenz et al. (1997) reported an increase in peach fruit mass at higher $\mathrm{N}$ rates. Increased frequency of fertilizer application at the north-central site compared with the other sites may have also helped ensure that adequate mineral nutrients were available for plant growth throughout the FDP.

Table 3. Fruit development period, fruit weight, and fruit quality measurements for four low-chill peach cultivars during 2005 for central and southwest Florida.

\begin{tabular}{|c|c|c|c|c|c|c|}
\hline & $\begin{array}{l}\text { FDP }^{z} \\
\text { (days) }\end{array}$ & $\begin{array}{c}\mathrm{TA}^{\mathrm{y}} \\
(\mathrm{mL} \mathrm{NaOH})\end{array}$ & $\begin{array}{c}\mathrm{SSC}^{\mathrm{x}} \\
\left({ }^{\circ} \text { Brix }\right)\end{array}$ & $\begin{array}{c}\text { Ratio } \\
\text { (SSC/TA) }\end{array}$ & Blush (\%) & Wt (g) \\
\hline \multicolumn{7}{|l|}{ Central } \\
\hline \multicolumn{7}{|l|}{ Cultivar } \\
\hline Flordaprince & $71 \mathrm{bB}^{\mathrm{w}}$ & $0.90 \mathrm{bA}$ & $11.5 \mathrm{aB}$ & $13.0 \mathrm{bB}$ & $62.2 \mathrm{aB}$ & $131.3 \mathrm{bA}$ \\
\hline Flordaglo & $74 \mathrm{bB}$ & $1.09 \mathrm{aA}$ & $11.9 \mathrm{aB}$ & $11.0 \mathrm{bB}$ & $52.9 \mathrm{bB}$ & $129.4 \mathrm{bA}$ \\
\hline UFGold & $65 \mathrm{cB}$ & $0.82 \mathrm{bA}$ & $12.0 \mathrm{aB}$ & $14.9 \mathrm{aB}$ & $46.3 \mathrm{cB}$ & $95.0 \mathrm{cA}$ \\
\hline TropicBeauty & $82 \mathrm{aB}$ & $1.05 \mathrm{aA}$ & $12.0 \mathrm{aA}$ & $11.6 \mathrm{bB}$ & $47.5 \mathrm{bcB}$ & $152.9 \mathrm{aA}$ \\
\hline \multicolumn{7}{|l|}{ Southwest } \\
\hline \multicolumn{7}{|l|}{ Cultivar } \\
\hline Flordaprince & $78 \mathrm{bA}$ & $0.83 \mathrm{abA}$ & $12.8 \mathrm{bA}$ & $15.6 \mathrm{bA}$ & $89.8 \mathrm{aA}$ & $86.3 \mathrm{bcB}$ \\
\hline Flordaglo & 95 aA & $0.89 \mathrm{aB}$ & $12.9 \mathrm{bA}$ & $14.6 \mathrm{bA}$ & $79.2 \mathrm{bA}$ & $100.5 \mathrm{abB}$ \\
\hline UFGold & $89 \mathrm{aA}$ & $0.74 \mathrm{bA}$ & $14.4 \mathrm{aA}$ & $20.2 \mathrm{aA}$ & $62.3 \mathrm{dA}$ & $75.2 \mathrm{cB}$ \\
\hline TropicBeauty & $95 \mathrm{aA}$ & $0.84 \mathrm{abB}$ & $12.3 \mathrm{bA}$ & $14.8 \mathrm{bA}$ & $72.5 \mathrm{cA}$ & $107.6 \mathrm{aB}$ \\
\hline
\end{tabular}

${ }^{\mathrm{z} F r u i t}$ development period.

y Titratable acidity, mL $0.1 \mathrm{~N} \mathrm{NaOH}$.

x Soluble solids content.

${ }^{w}$ Uppercase letters represent significant differences between locations for a specific cultivar. Lowercase letters represent significant differences among cultivars at a given location according to Tukey's test $(P \leq$ $0.05)$.

Table 4. Fruit development period, fruit weight, and fruit quality measurements for four low-chill peach cultivars during 2005 for north-central Florida.

\begin{tabular}{lcccccc}
\hline Cultivar & $\begin{array}{c}\mathrm{FDP}^{\mathrm{z}} \\
(\text { days })\end{array}$ & $\begin{array}{c}\mathrm{TA}^{\mathrm{y}} \\
(\mathrm{mL} \mathrm{NaOH})\end{array}$ & $\begin{array}{c}\mathrm{SSC}^{\mathrm{x}} \\
\left({ }^{\circ} \text { Brix }\right)\end{array}$ & $\begin{array}{c}\text { Ratio } \\
(\mathrm{SSC} / \mathrm{TA})\end{array}$ & Blush $(\%)$ & Wt $(\mathrm{g})$ \\
\hline Flordaprince & $91 \mathrm{~b}^{\mathrm{w}}$ & $0.92 \mathrm{bc}$ & $9.7 \mathrm{a}$ & $10.6 \mathrm{a}$ & $57.2 \mathrm{a}$ & $160.6 \mathrm{~b}$ \\
Flordaglo & $95 \mathrm{~b}$ & $1.10 \mathrm{a}$ & $9.4 \mathrm{a}$ & $8.6 \mathrm{~b}$ & $59.2 \mathrm{a}$ & $156.0 \mathrm{~b}$ \\
UFGold & $81 \mathrm{c}$ & $0.89 \mathrm{c}$ & $9.5 \mathrm{a}$ & $10.7 \mathrm{a}$ & $37.4 \mathrm{c}$ & $118.5 \mathrm{c}$ \\
TropicBeauty & $102 \mathrm{a}$ & $1.02 \mathrm{ab}$ & $10.3 \mathrm{a}$ & $10.1 \mathrm{ba}$ & $45.8 \mathrm{~b}$ & $171.7 \mathrm{a}$ \\
\hline
\end{tabular}

${ }^{\mathrm{z} F r u i t}$ development period.

${ }^{\mathrm{y}}$ Titratable acidity, mL $0.1 \mathrm{~N} \mathrm{NaOH}$.

xoluble solids content.

wLowercase letters represent significant differences among cultivars according to Tukey's test $(P \leq 0.05)$.
Both 'Floridaprince' and 'UFGold' were smaller than expected in central Florida during 2004 (Table 1). This was probably the result of an interruption in irrigation during Stage III of fruit growth for these cultivars. A break in the irrigation line occurred during the last 2 weeks of Mar. 2004, preventing irrigation of the planting. Water deficits during Stage III of fruit growth can reduce fruit size (Li et al., 1989). 'Flordaprince' and 'UFGold' have shorter FDPs than 'Flordaglo' or 'TropicBeauty'. Harvest of 'Flordaprince' and 'UFGold' began 2 weeks after the irrigation line was repaired, whereas harvest of 'Flordaglo' and 'TropicBeauty' began 3 to 4 weeks after the repair. Growth during Stage III of 'Flordaprince' and 'UFGold' was probably more directly affected by the interruption in irrigation than it was for 'Flordaglo' or 'TropicBeauty', which have longer FDPs and probably received more water during Stage III (final swell) of fruit growth.

During 2005, an overall pattern emerged for the north-central and central Florida locations where fruit weights were greatest for 'TropicBeauty' followed by 'Flordaprince', 'Flordaglo', and 'UFGold' (Tables 3 and 4). At the southwest site, mean fruit weight of 'TropicBeauty' was greater than 'UFGold' or 'Flordaprince' (Table 3). Fruit weights were greater for the central location than for the southwest location across all cultivars.

Fruit color varied among the different cultivars and locations. Generally the highest blush was observed for 'Flordaprince' and the lowest was observed for 'UFGold'. 'Flordaglo' also tended to have higher blush values than 'UFGold'. Blush values were often lower than what is stated in the cultivar release statements. Only at the southwest location did percent blush attain previously reported values for 'Flordaprince' and 'UFGold'. The release statements indicate that 'Flordaprince' has a blush of $\approx 80 \%$ and 'UFGold' has a blush of $\approx 70 \%$ to 90\% (Sherman and Lyrene, 1997; Sherman et al., 1982). We observed fruit blush values $\approx 60 \%$ for 'Flordaprince' and $\approx 40 \%$ for 'UFGold' at the north-central location during both years. In central Florida, 'UFGold' values were $\approx 45 \%$ and $60 \%$ during 2004 and 2005, respectively. Values for 'Flordaprince' were $60 \%$ to $65 \%$ during both seasons.

Table 5. Bloom dates and mean daily temperatures during fruit development of four low-chill peach cultivars grown at three locations in Florida.

\begin{tabular}{|c|c|c|c|c|c|c|c|c|c|c|c|c|}
\hline \multirow[b]{3}{*}{ Cultivar } & \multicolumn{4}{|c|}{ North-central } & \multicolumn{4}{|c|}{ Central } & \multicolumn{4}{|c|}{ Southwest } \\
\hline & \multicolumn{2}{|c|}{ Bloom date ${ }^{z}$} & \multicolumn{2}{|c|}{$\begin{array}{l}\text { Mean daily } \\
\text { temp. }\left({ }^{\circ} \mathrm{C}\right)\end{array}$} & \multicolumn{2}{|c|}{ Bloom date } & \multicolumn{2}{|c|}{$\begin{array}{l}\text { Mean daily } \\
\text { temp. }\left({ }^{\circ} \mathrm{C}\right)\end{array}$} & \multicolumn{2}{|c|}{ Bloom date } & \multicolumn{2}{|c|}{$\begin{array}{l}\text { Mean daily } \\
\text { temp. }\left({ }^{\circ} \mathrm{C}\right)\end{array}$} \\
\hline & 2004 & 2005 & 2004 & 2005 & 2004 & 2005 & 2004 & 2005 & 2004 & 2005 & 2004 & 2005 \\
\hline Flordaglo & 31 Jan. & $5 \mathrm{Feb}$. & 15.4 & 15.7 & $2 \mathrm{Feb}$. & $28 \mathrm{Feb}$. & 18.2 & 19.0 & 2 Feb. & 2 Feb. & 19.1 & 18.6 \\
\hline UF Gold & 13 Feb. & $12 \mathrm{Feb}$. & 15.8 & 15.8 & 9 Feb. & $28 \mathrm{Feb}$. & 18.1 & 18.7 & 31 Jan. & 31 Jan. & 19.2 & 18.2 \\
\hline Tropic Beauty & 31 Jan. & 2 Feb. & 15.5 & 15.8 & 28 Jan. & 23 Feb. & 17.5 & 19.2 & 1 Feb. & 1 Feb. & 19.5 & 17.7 \\
\hline
\end{tabular}

${ }^{\mathrm{z}}$ Estimated date of $50 \%$ to $60 \%$ bloom.

Accumulated chilling in 2004: 450 chill units (cu) for north-central, $249 \mathrm{cu}$ for central, and $151 \mathrm{cu}$ for southwest. Accumulated chilling in $2005: 400 \mathrm{cu}$ for northcentral, $162 \mathrm{cu}$ for central, and $130 \mathrm{cu}$ for southwest. 
Light distribution in the canopy can have an effect on fruit quality and color. Higher blush at the central and southwest locations than at the north-central location is probably the result of greater sunlight exposure of the fruit. Several studies have shown that increased light exposure can cause higher red blush in peaches (Erez and Flore, 1986; Kataoka and Beppu, 2004; Lewallen and Marini, 2003). High rates of vegetative growth at the north-central location from the additional fertilizer applications could have reduced fruit exposure to sunlight and resulted in less red color than at the other sites. Trees at the central and southwest locations had less canopy cover and the fruit had greater exposure to light. Generally blush values observed in southwest Florida agreed with previously reported information (Rouse and Sherman, 1989b; Sherman and Lyrene, 1989, 1997; Sherman et al., 1982). Higher blush values at the central and southwest locations may also be attributable in part to higher incidence of blind nodes caused by higher temperatures during bud development at these locations than in north-central Florida (Wert et al., 2007a). This would allow for greater sunlight penetration into tree canopies at the warmer locations. Fruit produced under such conditions would be expected to have high blush values.

Values for colorimeter measurements taken from the most-blushed portion of fruit during the 2005 harvest season were tightly clustered together when hue and chroma values were graphed together. All cultivars and locations were clustered, indicating that increased light levels tended to mask cultivar differences in the ability to produce blush (Fig. 1). Values for the location on the fruit with the lowest blush tended to be more scattered for all cultivars and locations. This indicates that there is higher genetic variation among cultivars for the ability to produce blush (pigment) on the fruit epidermis under shaded conditions.
With regard to internal quality, 'UFGold' was most notable. TA values were lowest for 'UFGold' across locations and the SSC:TA ratio tended to be highest for this cultivar. SSC values for 'UFGold' were similar to the other cultivars. Therefore, the higher value for the SSC:TA ratio for 'UFGold' resulted from the lower TA values. 'UFGold' is derived from clingstone germplasm and it is a nonmelting flesh peach. Nonmelting flesh peaches can be harvested at more advanced stages of fruit maturity and have a longer postharvest shelf life. The composition of organic acids in melting flesh peaches has been studied with malic acid being the predominant acid (Byrne et al., 1991). Differences in TA levels among the different maturity stages for nonmelting flesh peaches have also been studied with lower levels of TA observed at more advanced maturity levels (Brooks et al., 1993). However, information regarding differences in TA levels between nonmelting and melting flesh peaches at the same stage of maturity is not available in the literature and further research in this area is warranted.

Although statistical comparisons were not made, the north-central location generally had lower SSC and SSC:TA ratios than the other locations across all cultivars and for both years. Fruit quality can be affected by high amounts of $\mathrm{N}$ fertilization. Jia et al. (1999) concluded high $\mathrm{N}$ fertilizer rates inhibited sugar accumulation in peach. Fruit from trees at the north-central location that received higher $\mathrm{N}$ fertilizer rates generally had fruit with lower sugar content as measured in ${ }^{\circ}$ Brix. Excessive foliage from high $\mathrm{N}$ applications may have resulted in shading of fruit and nearby leaves resulting in lower fruit quality. Alternatively, vegetative growth and fruit growth represent competing sinks in peach (Mimoun et al., 1998). It is possible that excessive vegetative growth resulting from high $\mathrm{N}$ applications may have increased competition between developing shoots and

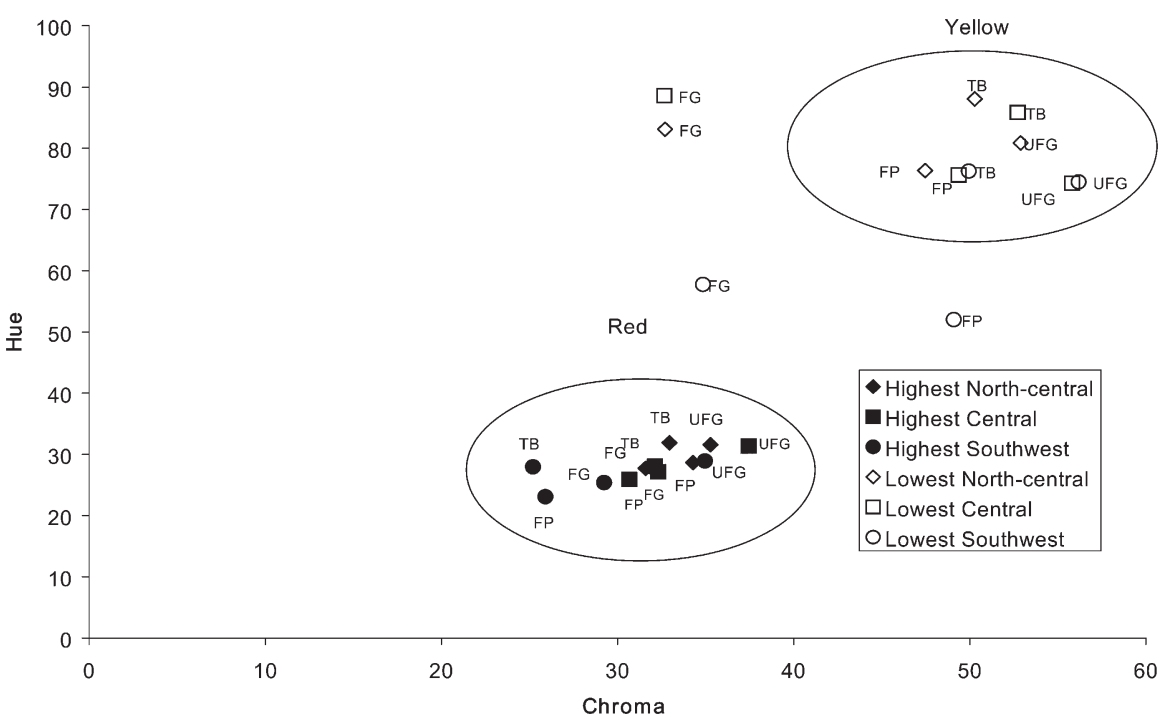

Fig. 1. Hue and chroma values for the highest and lowest blushed locations on four low-chill peach cultivars at three locations in Florida. fruit for assimilates during critical periods of fruit development, thereby reducing SSC content in mature fruit.

High SSC values in the central location during 2004 may be the result of the interruption of irrigation that occurred during Stage III of fruit growth. Water deficits during Stage III of development can increase the SSC in peach (Li et al., 1989). As described earlier, the timing of the interruption of irrigation may have more directly affected fruit development of 'Flordaprince' and 'UFGold' than the other two cultivars.

Crop load can have a significant impact on fruit quality of peach (Corelli-Grappadelli and Coston, 1991; Weinberger, 1931). In the present study, fruit yields per tree were determined for all cultivars at all locations and both years except for the southwest location in 2004. Percent fruit set was determined for all cultivars and both years at the north-central and central locations. Percent fruit set was higher for 'Flordaglo' and 'UFGold' than for 'Flordaprince' or 'TropicBeauty' at both locations, but no differences were observed between locations (data not shown). Fruit yields varied by cultivar but were within the normal range for low-chill, early season cultivars during their third and fourth growing seasons in Florida. During both years, differences in yield were much greater among cultivars at a given location than between locations for a specific cultivar. In 2004, 'Floridaprince' had the lowest yield of any cultivar at both locations, but only 'UFGold' had substantially different yields between locations with $0.37 \mathrm{~kg} /$ trunk crosssectional area (TCA) and $0.19 \mathrm{~kg} / \mathrm{TCA}$ at the north-central and central locations, respectively. In 2005, fruit yield ( $\mathrm{kg} / \mathrm{TCA})$ was higher for 'TropicBeauty' at the southwest location than at central Florida and tended to be lower for 'Flodaglo' at the north-central site than at the central site, although statistical comparisons of the north-central site with the other sites were not made (data not shown). The occasional differences found for crop load were not consistent with the general trends for differences in fruit quality measurements among locations suggesting that, in this study, crop load was not a major factor influencing fruit quality effects.

Weather in the form of precipitation and cloud cover may affect fruit quality if it occurs during the latter stages of fruit development (Kwon et al., 2008). Precipitation was low in 2004 at all sites during fruit harvest. However, in 2005, more rainfall occurred at the north-central site than at the southwest site and periods of cloudy weather occurred between 4 May and 6 May and between 31 May and 4 June at the northcentral location. There were approximately twice as many rain events during the harvest period in north-central Florida as in southwest Florida. The effects of rainfall and cloudy weather may have played a role in fruit quality differences among sites. However, because trees were irrigated, there were overall relatively few rainfall events during the harvest season, and fruit was harvested 
and measured frequently throughout this period, it appears that factors other than rainfall and cloudy weather played a critical role in fruit quality differences among sites.

The results presented in this article, and two related manuscripts (Wert et al., 2007a, 2007b), highlight the importance of environmental interactions in the growth and development of peach fruit and trees and emphasize the importance of adequate testing of released cultivars before recommendation for planting. Although chilling requirement may be one indicator of adaptation to a given region, other climatic factors such as temperature during fruit development may have significant direct, or indirect, effects on overall cultivar performance and fruit quality.

\section{Literature Cited}

Andersen, P.C. and W.B. Sherman. 1994. New low chill peach and nectarine cultivars from the University of Florida. Proc. Fla. State Hort. Soc. 107:331-333.

Batjer, L.P. and G.C. Martin. 1965. The influence of night temperature on growth and development of early Redhaven peaches. Proc. Amer. Soc. Hort. Sci. 87:1399-1404.

Boonprakob, U., D.H. Byrene, and R.E. Rouse. 1992. Response of fruit development period to temperature during specific periods after full bloom in peach. Fruit Varieties Journal. 46:137-140.

Brooks, S.J., J.N. Moore, and J.B. Murphy. 1993. Quantitative and qualitative changes in sugar content of peach genotypes [Prunus persica (L.) Batsch.]. J. Amer. Soc. Hort. Sci. 118:97-100.

Byrne, D.H. and T.A. Bacon. 1999. Founding clones of low-chill fresh market peach germplasm. Fruit Varieties Journal. 53:162-171.

Byrne, D.H., A.N. Nikolic, and E.E. Burns. 1991. Variability in sugars, acids, firmness, and color characteristics of 12 peach genotypes. J. Amer. Soc. Hort. Sci. 116:1004-1006.

Corelli-Grappadelli and D.C. Coston. 1991. Thinning pattern and light environment in peach tree canopies influence fruit quality. HortScience 26:1464-1466.

Erez, A. and J.A. Flore. 1986. The quantitative effect of solar radiation on 'Redhaven' peach fruit skin color. HortScience 21:1424-1426.

Jia, H.-J., K. Hirano, and G. Okamoto. 1999. Effects of fertilizer levels on tree growth and fruit quality of 'Hakuho' peaches (Prunus persica). J. Jpn. Soc. Hort. Sci. 68:487-493.

Kataoka, I. and K. Beppu. 2004. UV irradiance increases development of red skin color and anthocyanins in 'Hakuho' peach. HortScience 39:1234-1237.

Kwon, J.H., H.Y. Park, J.H. Jun, and H.J. Lee. 2008. Changes of sugar composition and related enzyme activities of 'Kansuki Hakuto' and 'Kurakatawase' peach after rainfall. Hort. Environ. Biotechnol. 49:85-89.

Lewallen, K.S. and R.P. Marini. 2003. Relationship between flesh firmness and ground color in peach as influenced by light and canopy position. J. Amer. Soc. Hort. Sci. 128:163170.

Li, S.-H., J.-G. Huguet, P.G. Schoch, and P. Orlando. 1989. Response of peach tree growth and cropping to soil water deficit at various phenological stages of fruit development. J. Hort. Sci. 64:541-552.

Lilleland, O. 1936. Growth study of the apricot fruit II: The effect of temperature. Proc. Amer. Soc. Hort. Sci. 33:269-279.

Lopez, G., R.S. Johnson, and T.M. DeJong. 2007. High spring temperatures decrease peach fruit size. Calif. Agr. 61:31-34.

Lyrene, P.M. 2005. Breeding low-chill blueberries and peaches for subtropical areas. HortScience 40:1947-1949.

Mimoun, M.B., M. Genard, and J. Besset. 1998 Assimilate allocation to vegetative and fruit growth. Acta Hort. 465:409-414.

Okie, W.R. 1998. Handbook of peach and nectarine varieties. UDSA-ARS Handbook no. 714.

Richards, G.D., G.W. Porter, J. Rodriguez, and W.B. Sherman. 1994. Incidence of blind nodes in low-chill peach and nectarine germplasm. Fruit Var. J. 48:199-202.

Rouse, R.E. and W.B. Sherman. 1989a. Low-chill peaches in south Texas and potential in central
Florida. Proc. Fla. State Hort. Soc. 102:193195.

Rouse, R.E. and W.B. Sherman. 1989b. 'TropicBeauty': A low-chilling peach for subtropical climates. HortScience 24:165-166.

Saenz, J.L., T.M. DeJong, and S.A. Weinbaum 1997. Nitrogen stimulated increases in peach yields are associated with extended fruit development period and increased fruit sink capacity. J. Amer. Soc. Hort. Sci. 122:772-777.

Salvador, M.E., L.A. Lizana, L.E. Luchsinger, E. Alonso, and E. Loyola. 1998. Locality effect on some fruit quality parameters in peaches and nectarines. Acta Hort. 465:447-454.

Sherman, W.B. and P.M. Lyrene. 1989. 'Flordaglo' peach. HortScience 24:396.

Sherman, W.B. and P.M. Lyrene. 1997. 'UFGold' peach. Fruit Varieties Journal 51:76-77.

Sherman, W.B. and P.M. Lyrene. 2003. Low chill breeding of deciduous fruits-University of Florida. Acta Hort. 622:599-603.

Sherman, W.B., P.M. Lyrene, J.A. Mortensen, and R.H. Sharpe. 1982. 'Flordaprince' peach. HortScience 17:988.

Topp, B.L. and W.B. Sherman. 1989a. The relationship between temperature and bloom-toripening period in low-chill peach. Fruit Varieties Journal. 43:155-158.

Topp, B.L. and W.B. Sherman. 1989b. Location influences on fruit traits of low-chill peaches in Australia. Proc. Fla. State Hort. Soc. 102:195199.

Weinberger, J.H. 1931. The relationship of leaf area to size and quality of peaches. Proc. Amer. Soc. Hort. Sci. 28:18-22.

Weinberger, J.H. 1948. Influence of temperature following bloom on fruit development period of Elberta peach. Proc. Amer. Soc. Hort. Sci. $51: 175-178$.

Wert, T.W., J.G. Williamson, J.X. Chaparro, E.P. Miller, and R.E. Rouse. 2007a. Node development of four low-chill peach cultivars at three locations in Florida. HortScience 42:15921595 .

Wert, T.W., J.G. Williamson, J.X. Chaparro, E.P. Miller, and R.E. Rouse. 2007b. The influence of climate on fruit shape of four low-chill peach cultivars. HortScience 42:1589-1591. 